\title{
1. The rise of authoritarian capitalism in the twenty-first century
}

As the twenty-first century dawned there was fresh optimism for the triumph of democracy over political authoritarianism. The end of the Cold War supposedly signaled the "end of history" and with it the rise of liberal democracy and the demise of authoritarian regimes worldwide. Associated with this promise was the spread of economic capitalism internationally. It was to be an era of peaceful democratic markets. As one commentator at the time famously declared:

What we may be witnessing is not just the end of the Cold War, or the passing of a particular period of post-war history, but the end of history as such: that is, the end point of mankind's ideological evolution and the universalization of Western liberal democracy as the final form of human government. (Fukuyama, 1989)

Yet the first decade of the new millennium has belied these optimistic expectations. While it is indeed an age of capitalist globalization, political authoritarianism has not only survived but seems to be gaining new steam. Moreover, it has done so in the name of preserving marketization nationally and trans-nationally.

This apparent contradiction between economic liberalization and political authoritarianism has raised questions about the contemporary role of capitalism as a positive force for democratization. Rather than transitioning previously totalitarian states toward democracy and deepening it within perceived established liberal states, globalization has instead been theorized as enhancing despotism and repressive policies. Economic liberalization is increasingly viewed as a national "shock" that requires an oppressive sovereign state to implement and maintain its commonly unpopular "reforms" (Klein, 2007). This has also brought to the forefront deeper concerns regarding the fundamental relation of capitalism to authoritarianism. In this regard, economists are pointing to the inherent function of marketization for creating and sustaining political oligarchy (Piketty, 2014). These fears have only been exacerbated following the 
financial crisis of 2008 alongside the rising power of authoritarian "great powers" internationally.

At stake then is how to account for this paradox, that the more economically liberal a country becomes, the greater its reliance on authoritarianism seems to be across contexts. More precisely, to illuminate how the deepening of marketization worldwide is contributing to the strengthening of explicitly dictatorial regimes and the illiberal policies progressively pursued by traditionally democratic states. What are the underlying dynamics driving this diverse "authoritarian capitalism" in the twenty-first century? How to explain the rise of authoritarian capitalism in the age of globalization? What does this reveal about the more fundamental relationship between political authoritarianism and economic capitalism?

\section{AIM}

These concerns are especially pressing given the resurgence of political authoritarianism in the twenty-first century. Indeed the new millennium has been witness to the appearance and strengthening of explicitly despotic and non-democratic regimes, notably Russia and China, all extolling their exclusive ability to properly and successfully guide their country's market transition. Just as worrying has been the growth of "illiberal democracies" (Zakaria, 1997; Velasco, 2013) whose authoritarian social policies belie their stated formal democratic institutions and economic commitment to liberalization. Somewhat less explored but in a similar vein have been fears regarding the authoritarian characteristics of established liberal democratic nations within "developed" liberal democratic capitalist economies associated with such policies as the "War on Terror" and "War on Drugs" (Henry et al., 2005; Steger, 2008). Many continue to fear the strengthening of the so-called "imperial executive" within these nominally democratic regimes in the new millennium (Schlesinger, 2004; O'Hehir, 2014; Yuhan, 2004).

What is at the root of this emerging and seemingly universal rise of "authoritarian capitalism"? How, specifically, are contemporary processes of economic globalization not only not diminishing these established forms of authoritarianism but positively contributing and reinforcing them in the present era? To answer these questions it is necessary to approach anew a more fundamental question - what is the general relationship between economic capitalism and political authoritarianism? In addressing this deeper concern it is then possible to begin addressing how globalization is currently reflective of and evolving this relationship 
in the making of diverse forms of "authoritarian capitalism." Crucial to such an investigation is to ask in what ways is the structural spread of capitalism internationally giving rise to renewed desires for an authoritarian politics and the legitimization of authoritarian policies?

\section{POLITICAL AUTHORITARIANISM AND GLOBALIZATION}

This book explores the relationship of economic capitalism and political authoritarianism within the contemporary era of globalization. The examination of this relationship has taken on increased importance with the rise of authoritarian capitalist states on the one hand and the deployment of authoritarian-style politics by ostensibly liberal democratic countries on the other. The proliferation of such a politics alongside intensified economic policies of marketization across the globe represents the emergence of diverse forms of authoritarian capitalism nationally and internationally. This manuscript illuminates the political legitimization and spread of capitalism through these different but connected authoritarian politics.

This analysis emerges out of these present-day challenges and attempts to contribute to a wide range of existing literature on this topic. Traditionally marketization has been inexorably linked with processes of democratic transition. More precisely, economic liberalization is meant to be a necessary condition for democratization (see most notably Dahl, 1989; Lipset, 1959; Moore, 1967; Muller, 1995). To this end, economic and political liberalization are theorized to have a complementary relationship, as the former creates the required conditions for the latter. Here, the emerging bourgeois class, formed in the transformation to a market economy, exists as an independent force challenging dictatorial rule and catalyzing the shift to liberal democracy. It follows logically, from this perspective, then that as marketization spreads globally so too will democracy.

Nevertheless, this dominant perspective has long been challenged by critical, especially Marxian, scholarship emphasizing the strong function of the state in maintaining capitalist, and often oligarchic, relations (Jessop, 1990; Plamenatz, 1992; Poulantzas, 1978). Here, governments worked in conjunction with dominant capitalist classes to ensure elite rule, facilitating political authoritarianism both informally and at times formally. Historically these theories were supported by the persistence of politically authoritarian yet economically capitalist states throughout the developing world during the Cold War period (see for instance Canak, 
1984; Robison, 1988; Serra, 1979). However, with the fall of the Soviet Union there was a renewed optimism about the positive role of marketization for fostering new democratic regimes (Fukuyama, 1989).

This debate has expanded recently to encompass broader discussions of the relation of democratization with globalization. Scholars increasingly focus on the effect of international factors such as marketization for positively producing democratic governments in replacement of authoritarian regimes (Drake, 1998; Whitehead, 1996). This positive view of economic liberalization as a force for democratization and against authoritarianism conforms to previous modernization theories. Economic globalization, in this sense, serves as a catalyst for a political liberalization globally. These theoretical assumptions, moreover, stand as a strong justification for policies of privatization across contexts in both developing and developed countries.

However, this positive relation has been put into question. By contrast, recent evidence suggests that policies of economic capitalism tend to weaken the prospect for political democracy nationally (O'Neal, 1994). Notably it is said to incentivize governments to pursue policies, often coercively, favoring foreign investors at the expense of popular opinion and welfare (Cox, 1996; Diamond, 1999; Gray, 1996). This view resonates with broader perspectives setting processes of marketization directly against the prospect for genuine democratic transitions due to its need for oligarchy and a strong government to legitimize such restructuring (Cammack, 1998; Im, 1987; Martin et al., 1997).

These insights resonate with recent literature chronicling the rise of enhanced political authoritarianism coupled with hyper marketization. These studies have been especially prevalent in former communist states. The fall of the Soviet Union brought with it expectations of democratization (Pickel, 1993). While this has occurred in many places nominally, the region has also experienced a preservation, and in many cases enhancement, of authoritarian forms of governance (Bunce, 2003; Heryanto, 1999). Russia is a prime example of this tension. Whereas it has successfully maintained an edifice of parliamentarianism, in practice the country has seen the retention of quite non-democratic features ranging from the presence of a "strong" national leader in Putin to the large influence of a new capitalist oligarchs (Ambrosio, 2009; Aslund, 2007; Gavrov, 2007; Hanson, 2007; Sautman, 1995; Schatz, 2009). Similarly inspired studies have concentrated on the proliferation of authoritarianism in East Asia, even as countries across the region have increasingly embraced economic liberalization (Chang, 2002; Gills, 2000; Han and Ling, 1998; Lingle, 1996a; Robison, 1988). China remains the foremost example of this "authoritarian capitalist" state - a government whose monopoly rule not 
only survives amidst marketization but who in fact uses its non-democratic power to further its capitalist economic agenda (Dirlik, 1997; Ma, 2009; Tsai, 2007; Winfield and Peng, 2005).

Emerging from such country-specific studies have been novel attempts to understand more generally this new combination of political authoritarianism and economic marketization. In particular, this phenomenon has been referred to as "soft authoritarianism." This label has been applied to a wide range of regimes internationally, all of whom have combined authoritarian rule with economic marketization (Prizel, 1997; Pei, 2000; Roy, 1994; So, 2002; Stubbs, 2001). More precisely, it has crystallized, at least in rhetoric, a popular vision of a strong nondemocratic state or leader for effectively implementing these changes for the sake of national progress and popular welfare (Gat, 2007; Rodan and Jayasuriya, 2009; Swyngedouw, 2000). Consequently, globalization has produced in its wake not only concrete authoritarian regimes but also a new authoritarian myth of capitalist development and socioeconomic prosperity (Beeson, 2010; Fu and Chu, 1996; So and Chan, 2002; Thompson, 2004).

Somewhat less explored, but in a similar vein, have been examinations of the authoritarian characteristics of established liberal democratic nations within "developed" capitalist economies. Perhaps not surprisingly, these have primarily focused on the "War on Terror" and its adoption of what for many appears to be traditionally authoritarian language and methods (Henry et al., 2005; Steger, 2008). Yet this tacit form of authoritarianism within liberal democratic settings is also witnessed in the quite prohibitive "War on Drugs," the rise of a prisonindustrial complex and the marginalization both in rhetoric and practice of groups such as immigrants and "benefit thieves" for explaining the nation's ills (Giroux, 2007; Hetherington and Weiler, 2009). This "liberal authoritarianism" has further been associated with, though problematically only limitedly and often without proper explanations, chronic economic problems such as recession and rising inequality.

These observations have led, in turn, to theoretical discussions explaining the persistence of such explicit and implicit authoritarianism to the global spread of "neoliberalism." According to this perspective, the proliferation of capitalism internationally is part of broader shift away from democratic forms of rule (Brownlee, 2007; Tickell and Peck, 2003). In its place will be new types of power, prioritizing the authority of corporations and their state allies on the one hand as well as the ability of individuals to "self-discipline" themselves in line with these marketbased values (Giroux, 2004; Ong, 2006, 2007). Present then is the 
legitimization of political authoritarianism, whether through nondemocratic regimes or everyday practices of coercion, in the service of furthering corporate globalization.

\section{NEW APPROACHES FOR UNDERSTANDING "AUTHORITARIAN CAPITALISM"}

There is no one explanation for exhaustively investigating or understanding political authoritarianism in relation to capitalism. As the above studies reveal, this is a multi-faceted issue that demands a wide array of perspectives and explanations. Globalization only adds to the complexity of this problem. Called for are perspectives that illuminate the deeper structural relation of capitalism to political authoritarianism as well as the historically specific ways such a politics is serving to legitimize and support global capitalism. To do so requires a theoretical framework that ably combines both structural and post-structural approaches. This would enable an investigation, at once general in its explanation and respecting of contextual differences, simultaneously into how economic liberalization catalyzes political authoritarianism and political authoritarianism discursively strengthens economic liberalization.

For this reason, it is imperative to study not only the material economy of globalization but its discursive and psychic economy as well. At stake is illuminating what types of subjects global capitalism is currently producing both in its generalizable practices and its shared identifications. This book draws, therefore, on an ideology and discourse approach for studying the current relation of political authoritarianism and economic liberalization. This perspective focuses on the role of dominant discourses for structuring social relations and identity according to its understandings (Laclau and Mouffe, 1986). Emphasized is the ability for a prevailing set of beliefs, understandings and values to organize a field of meaning according to its own rationale and logic. Howarth (2000: 102) describes a hegemonic project thus as one which strives to "weave together different strands of discourse in an effort to dominate or structure a field of meaning, thus fixing the identities of objects and practices in a particular way."

Hegemony is also reinforced at the affective level, as a dominant discourse psychologically "grips" subjects according to its constructed desires. The Lacanian concept of fantasy, employed by a number of Laclauian commentators (see especially Glynos and Stavrakakis, 2004), is key for understanding this process. Fantasy is defined as "the element 
which holds together a given community [that] cannot be reduced to the point of symbolic identification" (Žižek, 1993: 201). As such:

the bonds linking together its members always implies a shared relationship to the Thing, toward enjoyment incarnated ... If we are asked how we can recognise the presence of this Thing, the only consistent answer is that the Thing is present in that elusive entity called our "way of life." (ibid.)

Social identity is consequently formed around common fantasies promising shared wholeness, ideals regarding a potential "way of life" to be captured and strived toward. All social and political identity thus, to quote Stavrakakis, "is supported by a reference to a lost state of harmony, unity and fullness, a reference to a pre-symbolic Real which most political projects aspire to bring back" (Stavrakakis, 1999). Liberal democracy, for example, is not just a set of principles citizens rationally accept as correct. It is, additionally, a fantasy; seizing subjects psychologically in its utopian vision of a perfected and perfectible society based on reified values of freedom, individualism, collective self-determination and shared prosperity.

Importantly these fantasies have a dualistic structure. On the one hand they are sustained through reference to a positive "stabilizing" fantasy, as referred to in the examples above. On the other hand, these beatific visions are constantly placed under threat by the presence of a negative "destabilizing" fantasy. Returning to the example of liberal democracy, it is a politics that while often utopian in its sentiment and aims is nonetheless often desperately partisan and antagonistic in its actual politics. Conservatives imagine Liberals maliciously trying to prevent their vision of an idealized Christian market society from materializing while Liberals similarly demonize the evangelical Right for supposedly stopping a secular fairer market economy. Consequently, all hegemony is marked by the appearance of a utopian fantasy promising wholeness linked to a malevolent fantasy trying to prevent such enjoyment from ever coming to pass.

This work examines how a market ideology in a particular historical context - in this case contemporary globalization - is politically supported by cultural fantasies. More precisely, it aims to show how political authoritarianism has arisen as a diverse but nonetheless common political fantasy for legitimizing and strengthening economic capitalism globally. These efforts resonate with the various ways historically the state has attempted to promote itself as a sovereign actor able to effectively "guide" markets. These previous efforts may seem to have become outdated due to the "free market" neoliberal ideologies of the past several 
decades leading up to and continuing into the twenty-first century. Nevertheless, the goal of this book is to illuminate the ways this sovereign-based fantasy has arisen once again in this era of corporate globalization, attached to particular resurgent authoritarian values politically. A question that must be asked, thus, is how politics is a central and vital element to the contemporary global spread of neoliberalism?

\section{DEFINING ECONOMIC LIBERALIZATION AND POLITICAL AUTHORITARIANISM}

In order to set forth this argument it is important to clarify what is meant in the work by the terms political authoritarianism and economic liberalization. The latter will be defined first, as its meaning within the context of this work is more straightforward. The concept of economic liberalization is predominantly defined as the process by which a national economy becomes more market oriented, profit driven and placed within private hands. It is normally associated with the right of private property, wage labor, reduced state intervention into the economy and the relatively unregulated buying and selling of goods on the market. Processes of transition toward such a system are referred to as marketization. Of course, there is by no means total agreement as to a universal description of economic liberalization - for instance, some demand no public role in the economy and others a limited one or some proponents focus on macro considerations of economic growth as an indicator of economic health while others concentrate on the privatization of production and consumption on the micro level. However, there is a relative consensus as to the core tenants of principles, one which espouses a general commitment to capitalism.

The concept of authoritarianism is more ambiguous and therefore deserves greater analytical reflection. Traditionally, authoritarianism connotes a non-democratic regime (Gills, 2000; Vesta, 1999). More precisely, one which has not been legitimized by popular election or who upon election seeks to remain in power indefinitely. Authoritarianism is thus counterpoised to democracy, a relationship further transposed onto the opposition between capitalism and its economic competitors. Turning again to modernization theory, it is predominantly assumed that democracy and liberalization are partners in the struggle against authoritarianism and non-market "state-" based economic systems.

Recently, theorists from a wide range of perspectives have associated authoritarianism with themes of ideological openness. The sociologist Howard Gabennesch (1972) for instance, in the early 1970s linked 
authoritarianism, both as a politics and a personal framework for action, with ideological reification and the presence of a narrow "world view." Similarly, psychologists Adorno, Frenkel-Brunswick, Levinson and Sanford (1950) postulated the so-called "authoritarian personality," which resonated strongly with values of conformity and an unquestioned commitment to conventional values. Empirically, illiberal attitudes have been statistically associated with an authoritarian perspective (e.g. a desire for orthodoxy and acceptance of existing beliefs) stressing the need for orthodoxy and acceptance of existing belief - thus CanettiNisism (2004) found that the more orthodox one's religious views, the more authoritarian, and less democratically oriented one's political views tended to be.

Within the post-structuralist tradition, a normative and ethical commitment to ideological plurality, "openness" rather than essentialism, is a central component of its overall approach. Howarth (2000: 124) notes in this regard that:

a postfoundational perspective does not give rise to a certain set of political and ethical decisions - though it does rule some positions out - those based on essentialist presuppositions - for example. The assertion and justification of values are thus the result of an articulatory practice, rather than a necessary entailment.

Politically, this has spawned a rethinking of democracy highlighting the contingency, and therefore contestability, of prevailing norms and larger belief systems governing society. Laclau and Mouffe (1986: 149-93), among others, argue accordingly for a project of "radical democracy," which in recognizing the inherently contingent, incomplete nature of the social would render political institutions and identities more open to contestation and differing ideological perspectives. In their words: "This moment of tension, of openness, which gives the social its essentially incomplete and precarious character, is what every project of radical democracy should set out to institutionalize" (ibid.: 190). Consequently, it is a type of politics "founded not upon dogmatic postulation of any "essence of the social," but, on the contrary on affirmation of the contingency and ambiguity of every "essence," and on the constitutive character of social division and antagonism (ibid.: 193).

As alluded to in the previous discussion of the conception of "illiberal democracies" of a democratic hegemony, it can be seen that such accounts of democracy, and by association authoritarianism, are both structural and subjective in nature. The former speaks to the ways in which a particular entrenched ideology remains unquestioned for guiding 
individual actions and decisions and the latter refers to how subjects ethically experience and relate to a social belief system - either democratically (e.g. contingent, open to contestation, never complete in its explanatory ability) or authoritarian (e.g. essentialist, unquestioned and totalizing in its scope). In this respect, political authoritarianism can be judged according to the degree of ideological openness within a given context as well as the affective investment individuals place in political discourses empowering the state to preserve this status quo.

This work accepts, and seeks to unite, these more formal and informal accounts of political authoritarianism. It defines authoritarianism as the presence of a non-democratically elected government as well as a political culture with relatively little ideological debate or possibility of change. Furthermore, it connects such authoritarianism to the legitimized power given to governments to protect this hegemonic system through a range of formal and informal repressive practices. Importantly, these are not always simultaneous in their occurrence. For instance, a formally democratic society may rely on a rather closed set of ideological values, such as the United States and its commitment to economic capitalism. This is, also, of course not to assume that there is ever a society, field of meaning, free from any sort of closure. Instead it is discussion of the degree certain dominant norms, beliefs and subjectivities are available to contestation and possible transformation within an existing political terrain as well as the state and other sovereign institutions' accepted and often desired role for maintaining these entrenched socioeconomic relations.

However, it is the contention of this book that there is a positive and mutually reinforcing relationship between these two forms of political authoritarianism. To this end, the higher degree of ideological closure, the greater likelihood for formal political authoritarianism. The way ideological closure can give rise to and legitimize practices of political authoritarianism is important, whether in formal democracies or explicitly authoritarian regimes. Again, looking at the US context, the ideologically closed principles underlying the Bush administration's "War on Terror" served to catalyze and justify authoritarian practices such as the curtailing of civil liberties and refusal of habeas corpus to suspected terrorist prisoners.

This research focuses thus on the exact ways official attempts to ideologically objectify, and thus close debate around, capitalism have discursively reinforced political authoritarianism, both formally and informally, in different settings internationally. More precisely, how an unquestioned ideological commitment to economic liberalization linked 
to discourses of globalization has produced a structurally reinforcing and affectively appealing capitalist fantasy of authoritarian capitalism politically.

\section{OUTLINE}

This book will hopefully provide a fresh perspective for understanding the relationship of authoritarianism and capitalism both generally and as specific to this current era of globalization. To do so it will explore this diverse authoritarian politics of capitalism within a range of national and international contexts. It will do so by first providing a historical overview revealing the previous linking of capitalism ideologically and in practice with both democratic and authoritarian political discourses. Central to this historical account will be the ways capitalism dealt with ideological challenges, similar to other economic belief systems such as communism, through political fantasies that championed authoritarian governments and policies. It will then update this largely hidden authoritarian history of capitalism to the contemporary period revolving around discourses of globalization.

From this foundation it will examine the proliferation of capitalist fantasies of political authoritarianism in rising despotic "state market" powers such as Russia and China, "developing countries" like Singapore and Mexico who legitimize formal and informal authoritarian rule through discourses of "modernization" and "democratization," respectively. It will then shift its attention to longstanding liberal democratic regimes who have drawn on globalization discourses, such as the "War on Terror," for granting the state greater power to use "illiberal" measures to protect liberal democracy politically and neoliberalism economically. Following this investigation, it will interrogate the paradoxical way international capitalist institutions, notably the IMF and World Bank, have encouraged authoritarian capitalism at the national level in the name of maintaining a "responsible" international financial order. It will conclude by highlighting theoretically and empirically how the global spread of capitalism strengthens political authoritarianism.

The second chapter will provide a historical account linking the evolution of economic capitalism to political fantasies of progress. This will explore, in particular, the connection of marketization to affective discourses stressing at different times democracy, colonialism and political authoritarianism. It will also reveal how leaders attempted to deal with the inability of capitalism to always deliver on its promises of prosperity, especially in bourgeoning liberal democratic countries, with 
fantasies demonizing social groups involving the deployment of a range of authoritarian rhetoric and concrete methods.

Chapter 3 looks in more depth at how present-day globalization has contributed to these historical trends. The ideologically closed nature of corporate globalization, reflected in popular understandings of it as "inevitable," produces resurgent desires for personal and collective agency. These desires are translated politically into a renewed appeal to the power of the state to recapture this lost sense of freedom and collective self-determination. In particular, it presents the government as effectively able to shape and guide globalization for the needs of its citizens. Consequently, these longings for sovereign protection become channeled into affectively resonant capitalist discourses of political authoritarianism.

Chapter 4 will examine the growth of new national regimes combining traditional authoritarian politics with the promotion of intensified economic marketization. Focusing particularly on the cases of China and Russia, it will trace out the shared legitimization of this form of authoritarian politics and capitalist economics through a fantasy of state-led market progress. It will then reveal how the closed ideological nature of capitalism as a "global" economic project - one where other ideas of economic development are marginalized or repressed - contributes to a matching authoritarian politics revolving around the state's singular ability to popularly guide this "inevitable" marketization against internal and external enemies.

In a similar vein, Chapter 5 looks at how affective authoritarian discourses linked to values of "modernization" and "democratization" are legitimizing neoliberal development. In particular, it will concentrate on how policies of marketization and privatization within "developing" countries have been conjoined with explicit and implicit political fantasies extolling the dominant function of the state for achieving and preserving national development. It will do so through the case studies of Singapore and Mexico, where aspirations for economic and political "modernization" have been strategically deployed to justify authoritarian rule and marketization policies for advancing the country.

Chapter 6 investigates the seemingly paradoxical deployment of authoritarian political rhetoric and practices by established liberal democratic regimes. This can be witnessed, for instance, in the West's ongoing "War on Terror," as well as enhanced policing to deal with internal threats ranging from "terrorists" to "immigrants" to social deviants such as drug users and "benefit thieves." To explain this apparently contradictory phenomenon, the chapter will explore the displacement of social and economic dissatisfaction, structurally related to policies of increased 
financialization, onto a demonized external or internal "other." More precisely, it champions the ability of a state to extend its power politically to spread liberal democracy abroad and protect it at home, while accepting its dramatically retreating role economically. It will also reveal how this discourse of liberal authoritarianism actively prevents the development of more democratically substantive and empowering forms of politics, as well as geographically confining popular rule to national boundaries.

Chapter 7 surveys the use of authoritarian fantasies to legitimize capitalism globally. It will do so through examining the accepted power of international institutions such as the IMF and World Bank to dictate national policy to reflect a narrow neoliberal economic agenda. In particular, it emphasizes its empowering of national governments to police itself and its citizens for the sake of preserving a "responsible" global free market. Such national "self-disciplining" is connected to a broader fantasy of governments using their power, even if necessarily repressively, to ensure that their country can survive and flourish in this international capitalist order. It also reveals how this fantasy empowers international institutions such as the IMF to "discipline" fiscally "irresponsible" states.

The eighth and final chapter concludes with an analysis of the common connection between these various forms of authoritarian capitalism. It will highlight how this analysis reveals the positive and dangerous relationship between economic capitalism and political authoritarianism. It will discuss, in this respect, how corporate globalization is historically, politically, affectively and structurally producing authoritarian capitalism. 